\title{
Glucocorticoid-induced tumor necrosis factor receptor expression in patients with cervical human papillomavirus infection
}

\author{
Cacilda Tezelli Junqueira Padovani ${ }^{[1]}$, Camila Mareti Bonin ${ }^{[2]}$, Inês Aparecida Tozetti ${ }^{[3]}$, \\ Alda Maria Teixeira Ferreira ${ }^{[2]}$, Carlos Eurico dos Santos Fernandes ${ }^{[2]}$ \\ and Izaias Pereira da Costa ${ }^{[1]}$
}

[1]. Programa de Pós-Graduação em Saúde e Desenvolvimento da Região Centro-Oeste, Faculdade de Medicina, Universidade Federal de Mato Grosso do Sul, Campo Grande, MS. [2]. Centro de Ciências Biológicas e da Saúde, Universidade Federal de Mato Grosso do Sul, Campo Grande, MS. [3]. Programa de PósGraduação em Doenças Infecciosas e Parasitárias, Faculdade de Medicina, Universidade Federal de Mato Grosso do Sul, Campo Grande, MS.

\begin{abstract}
Introduction: The progression of human papillomavirus (HPV) infection in the anogenital tract has been associated with the involvement of cells with regulatory properties. Evidence has shown that glucocorticoid-induced tumor necrosis factor receptor (GITR) is an important surface molecule for the characterization of these cells and proposes that GITR ligand may constitute a rational treatment for many cancer types. We aimed to detect the presence of GITR and CD25 in cervical stroma cells with and without pathological changes or HPV infection to better understand the immune response in the infected tissue microenvironment. Methods: We subjected 49 paraffin-embedded cervical tissue samples to HPV DNA detection and histopathological analysis, and subsequently immunohistochemistry to detect GITR and CD25 in lymphocytes. Results: We observed that 76.9\% of all samples with high GITR expression were HPV-positive regardless of histopathological findings. High GITR expression (77.8\%) was predominant in samples with $\geq 1,000$ RLU/PCB. Of the HPV-positive samples negative for intraepithelial lesion and malignancy, $62.5 \%$ had high GITR expression. High GITR expression was observed in both carcinoma and high-grade squamous intraepithelial lesion (HSIL) samples $(\mathrm{p}=0.16)$. CD25 was present in great quantities in all samples. Conclusions: The predominance of high GITR expression in samples with high viral load that were classified as HSIL and carcinoma suggests that GITR ${ }^{+}$cells can exhibit regulatory properties and may contribute to the progression of HPV-induced cervical neoplasia, emphasizing the importance of GITR as a potential target for immune therapy of cervical cancer and as a disease evolution biomarker.
\end{abstract}

Keywords: Human papillomavirus. Immune response. Immunohistochemistry.

\section{INTRODUCTION}

Human papillomavirus (HPV) infects the basal and parabasal cells of squamous epithelium in the female anogenital tract, and HPV types 16, 18, 31,33, and 45 in particular are believed to put patients at high risk for the development of high-grade cervical intraepithelial neoplasia (CIN) and cervical carcinoma ${ }^{1}$.

Infection progression has been associated with several factors, including the persistence of HPV, the presence of high-risk oncogenic HPV types, high viral load, integration of viral DNA, and E6 and E7 viral oncoprotein activity ${ }^{1}$. Evidence shows that regulatory $\mathrm{T}$ cells $\left(\mathrm{T}_{\mathrm{reg}}\right)$ are also involved in the progression to cervical neoplasia in HPV-infected patients ${ }^{2-5}$. $\mathrm{HPV}$-specific $\mathrm{CD}^{+}$regulatory cells isolated from lymph node

Address to: Dra. Inês Aparecida Tozetti. FM/UFMS. Caixa Postal 549, 79070900 Campo Grande, MS, Brasil.

Phone: 5567 3345-7387

e-mail: ines.tozetti@ufms.br

Received 7 February 2013

Accepted 4 June 2013 biopsies of patients with cervical carcinoma were found to suppress proliferation and cytokine (interferon- $\gamma$, interleukin [IL]-2) production by responder $\mathrm{T}$ cells $\mathrm{s}^{5}$.

$\mathrm{T}_{\text {reg }}$ cells play a crucial role in modulating the elimination of pathogens and tumor antigens and perform their function through immunosuppressive cytokine production and immunosuppression induction mediated by cell-to-cell contact, having the ability to suppress the activation, proliferation, and effector function of different cell types contributing to the immune response $e^{6,7} . \mathrm{T}_{\text {reg }}$ cells are subdivided into several subpopulations, one being the natural $\mathrm{T}_{\text {reg }}$ cells $\left(\mathrm{CD} 4^{+} \mathrm{CD} 25^{+} \mathrm{T}_{\text {reg }}\right)$, which numerically represent the largest group of cells with suppressor activity ${ }^{8}$.

Studies show that $T_{\text {reg }}$ cells are activated with greater sensitivity than naïve effector $\mathrm{T}$ cells after antigenic stimulation, which has been attributed mainly to their semi-activated state that is thought to be due to the increased expression of CD25 ( $\alpha$-chain of the IL-2 receptor), glucocorticoid-induced tumor necrosis factor receptor (GITR) markers, and others ${ }^{9-11}$.

The detection of $\mathrm{T}_{\text {reg }}$ cells has been challenging owing to the lack of exclusive surface molecules for these cells. Studies have shown that the presence of transcription factor 
FOXP3 (forkhead box p3) is highly specific and that its transduction into naïve $T$ cells increases the molecular expression associated with $\mathrm{T}_{\text {reg }}$ cells, such as that of CD25 and GITR ${ }^{12,13}$.

Evidence shows that another characteristic surface molecule of cells with regulatory properties, $\mathrm{T}_{\mathrm{reg}}$ cells in particular, is the GITR $^{14}$ - a tumor necrosis factor receptor superfamily member - which is predominantly expressed in $\mathrm{CD} 25^{+} \mathrm{CD} 4^{+}$ $\mathrm{T}_{\text {reg }}$ cells and plays an important role in the regulation of mucosal immune responses ${ }^{15-19}$. Recent studies have demonstrated that in vivo GITR ligation using an agonist anti-GITR monoclonal antibody, DTA-1, can augment anti-tumor T-cell responses by modulating $\mathrm{T}_{\mathrm{reg}}$ cells, which makes targeting GITR a potential immunotherapeutic approach to cancer treatment ${ }^{20-22}$.

Given the findings that indicate the involvement of cells with regulatory properties, especially $\mathrm{T}_{\text {reg }}$ cells, in the progression of cervical malignant lesions ${ }^{3,4,23,24}$, this study aimed to detect both CD25 and GITR markers in lymphocytes of cervical stroma to better understand the immune response in the microenvironment of HPV infection, which may shed light on novel therapeutic interventions against intraepithelial neoplasia and cervical cancer of viral etiology, and perhaps also make GITR a possible candidate biomarker for disease evolution.

\section{METHODS}

\section{Samples}

Forty-nine patient cervical samples embedded in paraffin and selected on a non-probabilistic form by convenience sampling from 2000 to 2002 in the Cancer Prevention Center of Campo Grande, Mato Grosso do Sul, Brazil, were used. These samples previously underwent a Hybrid Capture II reaction (Digene, Gaithersburg, $\mathrm{MD}$, USA) to quantify the viral load for group B - high oncogenic risk types that were classified into scores from 0 to $3: 0$ (HPV-negative samples); 1 ( 1 to $<100 \mathrm{U}$ of light released for probe; relative light units/positive control to group B (RLU/PCB); 2 (100 to $<1,000$ RLU/PCB); and 3 ( $\geq 1,000$ RLU/PCB). On the basis of histopathological analysis, the samples were classified as lowgrade squamous intraepithelial lesions (LSIL) (CIN I); high-grade squamous intraepithelial lesions; (HSIL) (CIN II, III); carcinoma, and negative for intraepithelial lesion and malignancy (NILM).

\section{Immunohistochemistry of CD25 and GITR}

The Immunohistochemistry (IHC) reaction was developed using antigen retrieval with wet heat and $0.05 \mathrm{M}$ ethylenediaminetetraacetic acid (EDTA) $\mathrm{pH} 8.0$ for the detection of CD25 marker ${ }^{25}$ and $10 \mathrm{mM}$ Tris and $1 \mathrm{mM}$ EDTA for the GITR marker. The primary antibodies used included anti-human IL-2R (eBioscience ${ }^{\circledR}$, San Diego, CA, USA; clone B-B10/cod.BMS134) and anti-GITR (R\&D systems ${ }^{\circledR}$, Minneapolis, MN, USA; goat IgG/cod.AF689).

The detection system was a Universal LSAB + Kit/HRP $\left(\right.$ Dako $^{\circledR}$, Carpinteria, CA, USA), and diaminobenzidine $\left(\right.$ Dako $\left.^{\circledR}\right)$ was used as a chromogen. Counterstaining was performed in hematoxylin, and the slides were observed under common optical microscopy with $10 \times$ and $40 \times$ objective lenses. Samples showing brown staining on characteristic cells were considered positive. Human tonsil tissue was used as the external control of the reaction over which the primary antibody (positive control) and phosphate buffer $\mathrm{pH} 7.4$ containing 1\% albumin (negative control) was applied.

\section{Quantitative analysis}

According to the presence of immunomarked cells, the histological sections were classified in low (small quantities) and high (large quantities) scores. The slides were analyzed by 2 independent observers, previously calibrated $(\kappa=0.98)$, and the final result of discordant cases was obtained by common analysis to produce a consensus.

\section{Statistical analysis}

Analysis of the frequencies among the histopathological findings and viral load according to GITR expression intensity were compared using Fisher's exact test.

\section{Ethical considerations}

This study was approved by the Research Ethics Committee of the Universidade Federal de Mato Grosso do Sul, protocol number 975, July 31, 2007.

\section{RESULTS}

We observed a predominance of GITR in large quantities $(7 / 9 ; 77.8 \%)$ in the samples with $\geq 1,000$ RLU/PCB (viral load 3 ), although increases in viral load did not have a statistical correlation with high GITR expression $(\mathrm{p}=0.40)$. Regardless of histopathological findings, among all samples with high GITR expression, 76.9\% (20/26) were HPV-positive (viral load, 1-3). Among the NILM samples, 40\% (8/20) were HPVpositive (viral load, 1-3) and 62.5\% (5/8) of these showed high GITR expression, while among NILM-HPV negative samples (viral load, 0), only $33.3 \%$ (4/12) showed high GITR expression (Table 1).

A frequency analysis of the histopathological findings according to GITR expression intensity is shown in Table 2. High GITR expression was predominant in the carcinoma and HSIL samples $(\mathrm{p}=0.16)$ (Figure 1).

All samples showed intense staining for CD25 regardless of the result of viral load or histopathological findings (Figure 2).

\section{DISCUSSION}

In the present study, we observed that among the high GITR expression samples $76.9 \%$ were HPV-positive and $23.1 \%$ were HPV-negative. The expression of this marker was predominant in samples with high viral load as well as high-grade lesions and carcinoma.

A number of surface and secreted molecules have been associated with $\mathrm{T}_{\text {reg }}$, and GITR has been recognized as $\mathrm{CD} 4^{+}$ $\mathrm{T}_{\text {reg }}$ markers in mice and humans ${ }^{22,26,27}$. In this context, it is of interest that $\mathrm{GITR}^{+} \mathrm{T}_{\text {reg }}$ cells might be involved in the failure of 
TABLE 1 - Distribution of histopathological findings according to viral load and GITR expression ( $\mathrm{n}=49)$.

\begin{tabular}{|c|c|c|c|c|c|c|c|c|c|}
\hline \multirow[b]{2}{*}{ Viral load } & \multicolumn{2}{|c|}{$\begin{array}{l}\text { NILM } \\
\text { GITR }\end{array}$} & \multicolumn{2}{|c|}{$\begin{array}{l}\text { LSIL } \\
\text { GITR }\end{array}$} & \multicolumn{2}{|c|}{$\begin{array}{l}\text { HSIL } \\
\text { GITR }\end{array}$} & \multicolumn{2}{|c|}{$\begin{array}{c}\text { CA } \\
\text { GITR }\end{array}$} & \multirow[b]{2}{*}{ Total } \\
\hline & low & high & low & high & low & high & low & high & \\
\hline 0 & 8 & 4 & 0 & 0 & 0 & 1 & 0 & 1 & 14 \\
\hline 1 & 1 & 2 & 5 & 2 & 3 & 4 & 1 & 1 & 19 \\
\hline Total & 11 & 9 & 6 & 3 & 5 & 8 & 1 & 6 & 49 \\
\hline
\end{tabular}

GITR: glucocorticoid-induced tumor necrosis factor receptor; NILM: negative for intraepithelial lesion and malignancy; LSIL: low grade squamous intraepithelial lesion; HSIL: high grade squamous intraepithelial lesion; CA: carcinoma. Viral load - 0 (negative); 1 (1 to < 100 RLU/ PCB); 2 (100 to < 1,000 RLU/PCB); 3 ( $\geq 1,000$ RLU/PCB); RLU/PCB: relative light unit/positive controls to group B; GITR - low: small quantities of immunomarked cells; GITR - high: large quantities of immunomarked cells.

TABLE 2 - Frequence of histopathological findings according to the intensity of GITR expression.

\begin{tabular}{|c|c|c|c|c|c|c|c|c|}
\hline \multirow[b]{2}{*}{ GITR } & \multicolumn{8}{|c|}{ Histopathological (n/\%) } \\
\hline & $\mathrm{n}$ & $\%$ & $\mathrm{n}$ & $\%$ & $\mathrm{n}$ & $\%$ & $\mathrm{n}$ & $\%$ \\
\hline low & 11 & 55.0 & 6 & 66.7 & 5 & 38.5 & 1 & 14.3 \\
\hline high & 9 & 45.0 & 3 & 33.3 & 8 & 61.5 & 6 & 85.7 \\
\hline
\end{tabular}

GITR: glucocorticoid-induced tumor necrosis factor receptor; NILM: negative for intraepithelial lesion and malignancy; LSIL: low grade squamous intraepithelial lesion; HSIL: high grade squamous intraepithelial lesion; CA: carcinoma. GITR - low: small quantities of immunomarked cells; GITR - high: large quantities of immunomarked cells. $(p=0.16)$.

the immune system to control the development of HPV-induced cancer. Studies have demonstrated increased frequencies and suppressive activity of $\mathrm{T}_{\text {reg }}$ cells in patients with high-grade lesions and cervical cancer. In addition, compared to colorectal cancer, skin melanoma, and bronchial carcinoma, HPV-derived $\mathrm{CIN}$ lesions and cervical carcinomas have higher numbers of $\mathrm{T}_{\text {reg }}$ cells $^{23,24}$.

One study that investigated the influence of tumor-infiltrating $\mathrm{T}_{\text {reg }}$ cells on tumor-specific $\mathrm{T}$ cell responses found that $\mathrm{T}_{\text {reg }}$ cells in patients with liver cancer upregulated GITR expression compared with $\mathrm{T}_{\text {reg }}$ cells in tumor-free liver tissue and blood ${ }^{28}$. Another study identified increased numbers of $\mathrm{T}_{\text {reg }}$ GITR $^{+}$cells in tumorpositive lymph nodes compared with tumor-negative nodes in the same patient ${ }^{29}$. Both studies propose that GITR ligand could be a promising treatment for cancer and that GITR and GITR ligand are good candidates for disease evolution biomarkers.

Studies investigating the natural history of HPV infection have shown that viral clearance may vary from 4-16 months according to the virus' oncogenicity ${ }^{30-32}$. However, it has been observed that persistent infection with a higher likelihood of progression to high-grade lesions and invasive carcinoma can occur in the face of an ineffective immune response. In this context and considering that HPV infection is restricted to epithelial cells, the importance of the local immune response is highlighted, making the components present in the microenvironment crucial for lesion development or regression ${ }^{33-36}$. The role of GITR has been unclear until now, emphasizing the importance of the present study to clarify the immune response in the cervical microenvironment.

The presence of high GITR and CD25 expression levels found in HPV-derived CIN lesions and cervical carcinomas indicates that these cells may play an important role in the downregulation of immune responses ${ }^{37}$. A strong association between these markers and $\mathrm{T}_{\text {reg }}$ cells was demonstrated in a study that found GITR expression in only those cells that also expressed CD4 and CD25, and most of them co-expressed FOXP $3^{38}$. The association of GITR and CD25 with negatively regulated $\mathrm{T}$ helper-activated lymphocytes has been demonstrated in experiment with C57BL/6 GITR ${ }^{+/+}$mice (wild type), which showed decreased IL-2 expression compared to C57BL/6 GITR $^{-1-39}$.

The relevance of cells expressing the studied markers in immune response suppression is emphasized by studies that evaluate in vitro regulatory activity through cytokine expression by $\mathrm{CD}^{+}{ }^{+} \mathrm{T}$ cells, $\mathrm{CD} 4^{+} \mathrm{CD} 25^{+} \mathrm{GITR}^{+}$cells, and $\mathrm{CD} 4^{+} \mathrm{CD} 25$ $\mathrm{GITR}^{+}$cells. These studies showed that the first produced cytokines that activated the immune response and the last 2 increased immunosuppressive cytokine levels ${ }^{15,17}$. 

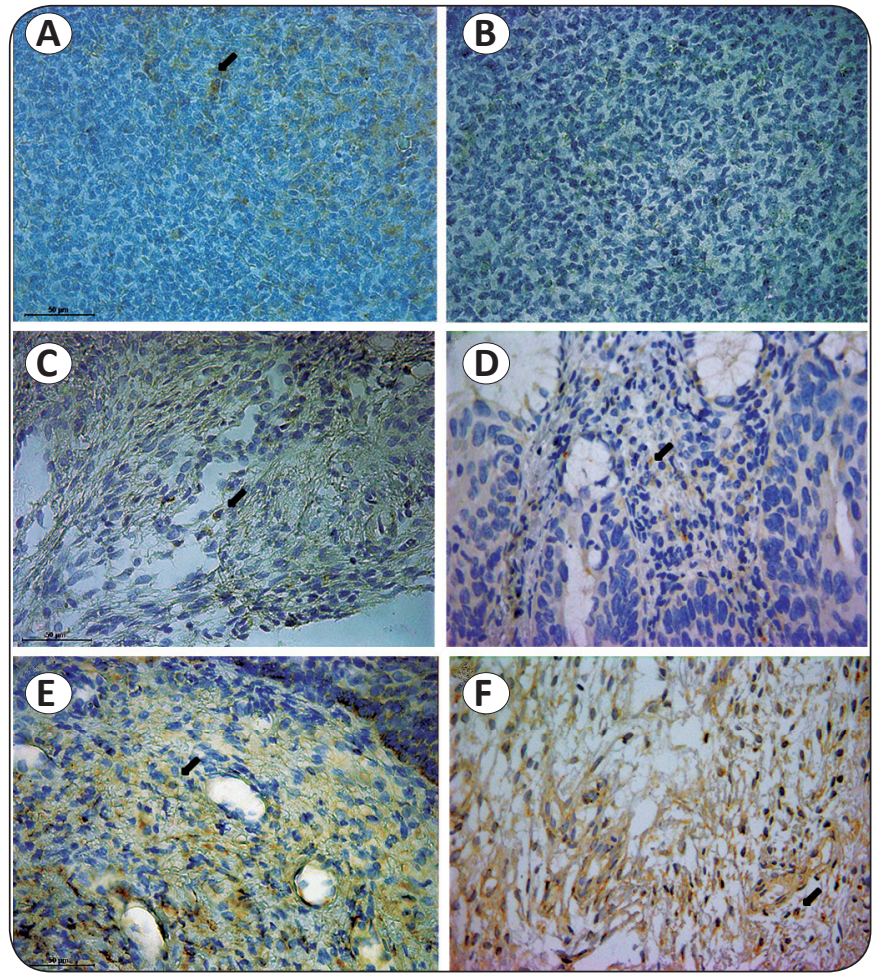

FIGURE 1 - GITR expression in HPV positive cervical lesions. a: positive control human tonsil stained with anti-human GITR antibody; b: negative control human tonsil - omitting primary antibody, showed no staining; c: CIN II and d: NILM, with GITR expressing cells in small quantities; e: CIN III and f: CIN I, with GITR expressing cells in large quantities. All figures are presented in the same magnification (400X). Black arrows indicate positive-staining cells with anti-human GITR antibody. GITR: glucocorticoid-induced tumor necrosis factor receptor; HPV: human papillomavirus; CIN: cervical intraepithelial neoplasia.
It is unclear whether increased frequencies of regulatory cells are a cause or consequence of high viral load and chronic infection ${ }^{2,40,41}$. The predominant expression of GITR in samples with high viral load and classified as HSIL and carcinoma in this study suggest that $\mathrm{GITR}^{+}$cells can exhibit regulatory properties. The lack of a correlation between GITR and viral load or GITR and histopathological findings can be explained by the small sample size. Additional studies are required to confirm these observations.

Further longitudinal studies are required to assess the true association between HPV persistence and immunoregulatory cell involvement in lesion progression and the development of neoplasia. Studies have demonstrated increased frequencies and suppressive activity of $\mathrm{T}_{\text {reg }}$ cells in HPV-infected patients with cervical cancer and its precursor lesions (CIN) and suggest that $\mathrm{T}_{\text {reg }}$ cells may be a potential marker of cervical disease persistence. One longitudinal analysis of $\mathrm{T}_{\text {reg }}$ cell frequencies showed a modest decline 1 year after curative surgery or chemoradiation ${ }^{3,4}$.

Finally, on the basis of the finding that GITR configures a surface molecule characteristic of cells with a regulatory profile, our results suggest that $\mathrm{GITR}^{+}$cells may play a role in the development of a favorable microenvironment for the progression of HPV-induced cervical neoplasia that omits proper activation of the immune response for antigen elimination. Additional studies have been made by the same group including the characterization of $\mathrm{FOXP}^{+} / \mathrm{CD} 25^{+}, \mathrm{CD} 4^{+} /$transforming growth factor- $\beta^{+}$and IL-10 - secreting cells in HPV-infected samples by using IHC to help elucidate the role of $\mathrm{T}_{\text {reg }}$ cells in cervical intraepithelial neoplasia (CIN) and cervical cancer (manuscript in preparation).
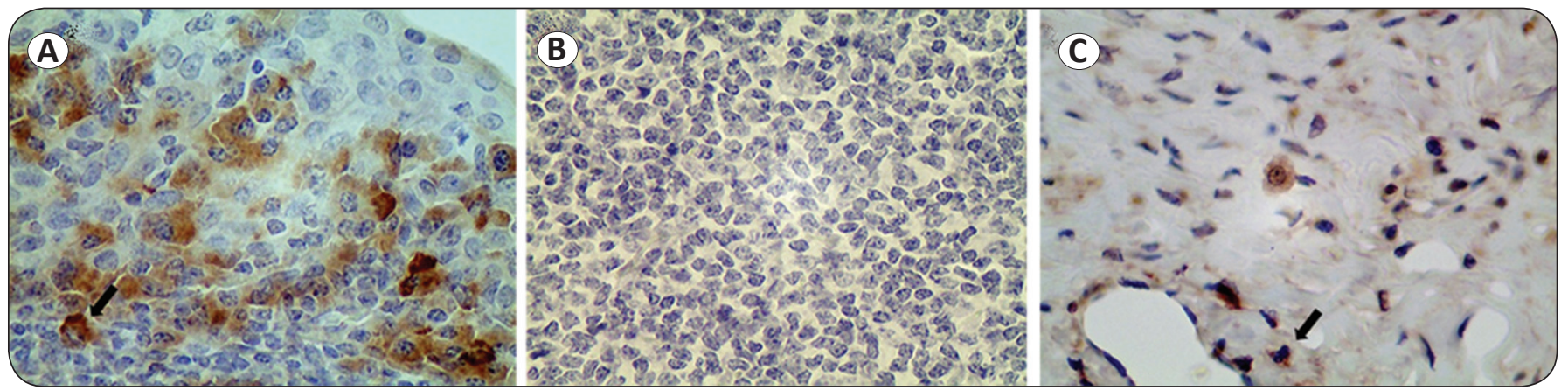

FIGURE 2 - CD25 expression in HPV positive cervical lesions. A: Positive control human tonsil stained with anti-human IL-2R antibody; B: negative control human tonsil - omitting primary antibody, showed no staining; C: CIN II, with CD25 expressing cells in large quantities. All figures are presented in the same magnification (400X). Black arrows indicate positive-staining cells with anti-human IL-2R antibody. HPV: human papillomavirus; IL-2R: IL-2 receptor; CD25: $\alpha$-chain of the IL-2 receptor.

\section{CONFLICT OF INTEREST}

The authors declare that there is no conflict of interest.

\section{FINANCIAL SUPPORT}

Fundação de Apoio ao Desenvolvimento do Ensino,
Ciência e Tecnologia de Mato Grosso do Sul (FUNDECT/ MS) and Conselho Nacional de Desenvolvimento Cientifico e Tecnológico (CNPq).

\section{REFERENCES}

1. International Agency for Research Cancer (IARC). Working group on the evaluation of carcinogenic risks to humans. IARC monographs on 
the evaluation of carcinogenic risk to humans. Human Papilomaviruses. Lyon: IARC Monographs; 2007.

2. Molling JW, Gruijl TD, Glin J, Moreno M, Rozedaal L, Meijer CJLM, etal.CD4+CD25 highregulatory Tcell frequency correlates with persistence of human papillomavirus type 16 and $\mathrm{T}$ helper cell responses in patients with cervical intraepithelial neoplasia. Int J Cancer 2007; 121:1749-1755.

3. Visser J, Nijman HW, Hoogenboom BN, Jager P, Van Baarle D, Schuuring E, et al. Frequencies and role of regulatory T cells in patients with (pre) malignant cervical neoplasia. Clin Exp Immunol 2007; 150:199-209.

4. Adurthi S, Krishna S, Mukherjee G, Bafna UD, Devi U, Jayshree RS. Regulatory $\mathrm{T}$ cells in a spectrum of HPV-induced cervical lesions: cervicitis, cervical intraepithelial neoplasia and squamous cell carcinoma. Am J Reprod Immunol 2008; 60:55-65.

5. Van der Burg SH, Piersma SJ, Jong A, Van der Hulst JM, Kwappenberg KM, Van den Hende M, et al. Association of cervical cancer with the presence of $\mathrm{CD} 4+$ regulatory $\mathrm{T}$ cells specific for human papillomavirus antigens. Proc Natl Acad Sci USA 2007; 104:12087-12092.

6. Von Boehmer H. Mechanisms of suppression by suppressor T cells. Nat Immunol 2005; 6:338-344.

7. Cruvinel WM, Mesquita DJ, Araújo JAP, Salmazi KC, Kállas EG, Andrade LEC. Natural Regulatory T cells in Rheumatic Diseases. Rev Bras Reumatol 2008; 48:342-355.

8. Sakaguchi S, Sakaguchi N, Asano M, Itoh M, Toda M. Immunologic self-tolerance maintained by activated T cells expressing IL-2 receptor $\beta$-chains (CD25): breakdown of a single mechanism of self tolerance causes various autoimmune diseases. J Immunol 1995; 155:1151-1164.

9. Itoh M, Takahashi T, Sakaguchi N, Kuniyasu Y, Shimizu J, Otsuka F, et al. Thymus and autoimmunity: production of $\mathrm{CD} 25+\mathrm{CD} 4+$ naturally anergic and suppressive $\mathrm{T}$ cells as a key function of the thymus in maintaining immunologic self-tolerance. J Immunol 1999; 162:5317-5326.

10. Takahashi T, Tagami T, Yamazaki S, Uede T, Shimizu J, Sakaguchi N, et al. Immunologic self-tolerance maintained by $\mathrm{CD} 25(+\mathrm{CD} 4(+)$ regulatory $\mathrm{T}$ cells constitutively expressing cytotoxic $\mathrm{T}$ lymphocyte-associated antigen 4. J Exp Med 2000; 192:303-310.

11. Yamaguchi T, Hirota K, Nagahama K, Ohkawa K, Takahashi T, Nomura $\mathrm{T}$, et al. Control of immune responses by antigen-specific regulatory $\mathrm{T}$ cells expressing the folate receptor. Immunity 2007; 27:145-159.

12. Rudensky AY. Regulatory T cells and Foxp3. Immunol Rev 2011; 241:260-268.

13. Ohkura N, Sakaguchi S. Regulatory T cells: roles of T cell receptor for their development and function. Semin Immunopathol 2010; 32:95-106.

14. Bushell A, Wood K. GITR ligation blocks allograft protection by induced $\mathrm{CD} 25+\mathrm{CD} 4+$ regulatory $\mathrm{T}$ cells without enhancing effector $\mathrm{T}$-cell function. Am J Transplant 2007; 7:759-768.

15. Shimizu J, Yamazaki S, Takahashi T, Ishida Y, Sakaguchi S. Stimulation of CD25+ CD4+ regulatory T cells through GITR breaks immunological selftolerance. Nat Immunol 2002; 3:135-142.

16. McHugh RS, Whitters MJ, Piccirillo CA, Young DA, Shevach EM, Collins $\mathrm{M}$, et al. CD4+CD25+ immunoregulatory T cells: gene expression analysis reveals a functional role for the glucocorticoid-induced TNF receptor. Immunity 2002; 16:311-323.

17. Uraushihara K, Kanai T, Ko K, Totsuka T, Makita S, Iiyama R, et al. Regulation of murine inflammatory bowel disease by CD25+ and CD25-CD4+ glucocorticoid-induced TNF receptor family-related gene+ regulatory T cells. J Immunol 2003; 171:708-716.

18. Sakaguchi S. Naturally arising CD4+ regulatory T cells for immunologic self-tolerance and negative control of immune responses. Annu Rev Immunol 2004; 22:531-562.

19. Negrini S, Fenoglio D, Balestra P, Fravega M, Filaci G, Indiveri F. Endocrine regulation of suppressor lymphocytes: role of the glucocorticoid-induced TNF-like receptor. Ann N Y Acad Sci 2006; 1069:377-385.

20. Cohen AD, Schaer DA, Liu C, Li Y, Hirschhorn-Cymmerman D, Kim SC, et al. Agonist anti-GITR monoclonal antibody induces melanoma tumor immunity in mice by altering regulatory $\mathrm{T}$ cell stability and intra-tumor accumulation. PLoS One 2010; 5:e10436.

21. Hoffmann C, Stanke J, Kaufmann AM, Loddenkemper C, Schneider A, Cichon G. Combining T-cell vaccination and application of agonistic anti-GITR mAb (DTA-1) induces complete eradication of HPV oncogene expressing tumors in mice. J Immunother 2010; 33:136-145.
22. Bianchini R, Bistoni O, Alunno A, Petrillo MG, Ronchetti S, Sportoletti P, et al. CD4(+) CD25(low) GITR (+) cells: a novel human CD4(+) T-cell population with regulatory activity. Eur J Immunol 2011; 41:2269-2278.

23. Loddenkemper C, Hoffmann C, Stanke J, Nagorsen D, Baron U, Olek $\mathrm{S}$, et al. Regulatory (FOXP3+) T cells as target for immune therapy of cervical intraepithelial neoplasia and cervical cancer. Cancer Sci 2009; 100:1112-1117.

24. Visser J, Nijman HW, Hoogenboom BN, Jager P, Van Baarle D, Schuuring $\mathrm{E}$, et al. Frequencies and role of regulatory $\mathrm{T}$ cells in patients with (pre) malignant cervical neoplasia. Clin Exp Immunol 2007; 150:199-209.

25. Santos ALF, Derchain SFM, Martins MR, Nonogaki S, Pinto GA. Procedimentos laboratoriais em imunohistoquímica e hibridização in situ. In: Alves VAF, Bacchi C, Vassalo J, editors. Manual de imunohistoquimica. $1^{a}$ ed. São Paulo: Sociedade Brasileira de Patologia; 1999 p. 237-259.

26. McHugh RS, Whitters MJ, Piccirillo CA, Young DA, Shevach EM, Collins $\mathrm{M}$, et al. $\mathrm{CD} 4(+) \mathrm{CD} 25(+)$ immunoregulatory $\mathrm{T}$ cells: gene expression analysis reveals a functional role for the glucocorticoidinduced TNF receptor. Immunity 2002; 16:311-323.

27. Shimizu J, Yamazaki S, Takahashi T, Ishida Y, Sakaguchi S. Stimulation of $\mathrm{CD} 25(+) \mathrm{CD} 4(+)$ regulatory T cells through GITR breaks immunological self-tolerance. Nat Immunol 2002; 3:135-142.

28. Gonzalez AP, Verhoef C, Ijzermans JNM, Peppelenbosch MP, Kwekkeboom J, Verheij J, et al. Activated tumor-infiltrating CD4+ regulatory T cells restrain antitumor immunity in patients with primary or metastatic liver cancer. Hematology 2013; 57:183-194.

29. Krausz LT, Fischer-Fodor E, Major ZZ, Fetica B. GITR-expressing regulatory T-cell subsets are increased in tumor-positive lymph nodes from advanced breast cancer patients as compared to tumor-negative lymph nodes. Int J Immunopathol Pharmacol 2012; 25:59-66.

30. Schiffman M, Kjar S. Natural history of anogenital human papillomavirus infection and neoplasia. J Natl Cancer Inst Monogr 2003; 31:14-19.

31. Trottier H, Franco EL. The epidemiology of genital human papillomavirus infection. Vaccine 2006; 24 (suppl I):1-15.

32. Tota JE, Chevarie-Davis M, Richardson LA, Devries M, Franco EL. Epidemiology and burden of HPV infection and related diseases: implications for prevention strategies. Prev Med 2011; 53 (supl I):12-21.

33. Bais AG, Beckmann I, Lindemans J, Ewing PC, Meijer CJ, Snijders PJ, et al. A shift to a peripheral Th2-type cytokine pattern during the carcinogenesis of cervical cancer becomes manifest in CIN III lesions. J Clin Pathol 2005; 58:1096-1100.

34. Fernandes Jr PC, Garcia CB, Micheli DC, Cunha FQ, Murta EF, TavaresMurta BM. Circulating neutrophils may play a role in the host response in cervical cancer. Int J Gynecol Cancer 2007; 17:1068-1074.

35. BalkwilL F, Mantovani A. Inflammation and cancer: back to Virchow? Lancet 2001; 357:539-545.

36. Fine JS, Byrnes HD, Zavodny PJ, Hipkin RW. Evaluation of signal transduction pathways in chemoattractant-induced human monocyte chemotaxis. Inflammation 2001; 25:61-66.

37. Brusko TM, Wasserfall CH, Hulme MA, Cabrera R, Schatz D, Atkinson MA. Influence of membrane CD25 stability on T lymphocyte activity: implications for immunoregulation. PLoS One 2009; 4:e7980.

38. De Boer OJ, Van Der Loos CM, Teeling P, Van Der Wal AC, Teunissen MB. Immunohistochemical analysis of regulatory T cell markers FOXP3 and GITR on CD4+CD25+ T cells in normal skin and inflammatory dermatoses. Journal of Histochemistry \& Cytochemistry 2007; 55: 891-898.

39. Ronchetti S, Nocentini G, Riccardi C, Pandolfi PP. Role of GITR in activation response of T lymphocytes. Blood 2002; 100:350-352.

40. Sugimoto K, Ikeda F, Stadanlick J, Nunes FA, Alter HJ, Chang KM. Suppression of HCV-specific T cells without differential hierarchy demonstrated ex vivo in persistent HCV infection. Hepatology 2003; 38:1437-1448.

41. Boettler T, Spangenberg HC, Neumann-Haefelin C, Panther E, Urbani S, Ferrari $\mathrm{C}$, et al. T cells with a $\mathrm{CD} 4^{+} \mathrm{CD} 25^{+}$regulatory phenotype suppress in vitro proliferation of virus-specific $\mathrm{CD}^{+} \mathrm{T}$ cells during chronic hepatitis C virus infection. J Virol 2005; 79:7860-7867. 